\title{
JOSEPH KRAUSKOPF'S EVOLUTION AND JUDAISM: ONE REFORM RABBI'S RESPONSE TO SCEPTICISM AND MATERIALISM IN NINETEENTH-CENTURY NORTH AMERICA
}

\author{
Daniel R. Langton*
}

\begin{abstract}
Popular culture's fascination with scepticism and science provoked a number of responses from Reform rabbis in late nineteenth-century North America. Darwin's theory of natural selection, which suggested that purely materialistic mechanisms accounted for the variety of life, and biblical-criticism, which implied that the irrational elements of the Bible made it largely irrelevant to faith of the modern, sceptical Jew, were just two prominent examples of the kind of ideas that challenged the traditional status quo. Several prominent Reform rabbis responded with Jewish theologies that encompassed organic evolutionary theory while espousing biblical creationism of one sort or another. Joseph Krauskopf was one such rabbi whose Evolution and Judaism (1887) adopted a sceptical approach to traditional readings of the bible and yet which, in attempting to justify Jewish religious continuity, taught a Jewish form of panentheism that viewed the universe as an evolving phenomenon and hinted at the reality of life beyond death.
\end{abstract}

\section{Introduction}

The inroads made by science and scepticism into popular culture were a constant source of concern for Reform rabbis in late nineteenth-century North America. Darwinism represented one clear and present danger, and biblical-criticism another. The first suggested that purely materialistic mechanisms accounted for the variety of life, and the second that the irrational elements of the Bible made it largely irrelevant to the faith of the modern, sceptical Jew. In response to such challenges, a number of Reform rabbis developed Jewish theologies of biological evolution that discussed, among other things, biblical creationism. Examples include Isaac Mayer Wise, Kaufmann Kohler and Emil G. Hirsch. ${ }^{1}$ One particularly interesting example was Joseph Krauskopf, whose Evolution and Judaism (1887) was one of the most comprehensive treatments of the subject. He espoused

\footnotetext{
* Professor of the History of Jewish-Christian Relations at the University of Manchester. Email: daniel.langton@ manchester.ac.uk

${ }^{1}$ A comprehensive study of Reform Jewish perspectives on evolutionary theory is in preparation by the author; in the meantime, see Daniel R. Langton, "Isaac Mayer Wise, Cosmic Evolution, and the Problem of Evil," in Chance or Providence? Religious Perspectives on Divine Action, ed. Louise Hickman (Cambridge: Cambridge Scholars Publishing, 2014). Wise's main work was Isaac Mayer Wise, The Cosmic God: A Fundamental Philosophy in Popular Lectures (Cincinnati: Office American Israelite and Deborah, 1876). The subject is discussed a number of times in Kaufmann Kohler, Jewish Theology: Systematically and Historically Considered (New York: The Macmillan Company, 1918), as well as in Kaufmann Kohler, "Science and Religion," The Jewish Times, 20 February 1874; Kaufmann Kohler, "Evolution and Morality," Temple Beth-El Lectures, pamphlet series, lecture delivered 4 December 1887 (New York, [1887/88?]); Kaufmann Kohler, "Adam: Or Man in Creation," The Jewish Messenger, 24 October 1879. Hirsch was perhaps the most prolific on the subject with publications including Emil G. Hirsch, "Evolution," in Jewish Encyclopedia, ed. Isadore Singer (New York: Funk and Wagnalls Company, 1901-1906); Emil G. Hirsch, "Evolution in Religion," The Jewish Advance, 6 May 1881; Emil G. Hirsch, Darwin and Darwinism: A Discourse Delivered before the Chicago Sinai Congregation (Chicago: Occident, 1883); Emil G. Hirsch, "The Doctrine of Evolution and Judaism," in Some Modern Problems and Their Bearing on Judaism, Reform Advocate Library (Chicago: Bloch \& Newman, 1903).
} 
a vehemently sceptical approach to tradition and scriptures and yet, at the same time, a panentheistic vision of an evolving universe that attempted to justify belief in immortality.

Joseph Krauskopf (1858-1923) was born in Ostrowo in Prussian Posen and emigrated to the US in 1872. He was a graduate of the first class of candidates for the rabbinate at the Reform rabbinical training college Hebrew Union College (HUC) in 1883 and received a doctoral degree, also from HUC, in $1885 .{ }^{2} \mathrm{He}$ became one of the most influential communal rabbis of his day, co-founding in 1888 the inter-denominational Jewish publishing house known as the Jewish Publication Society, serving two terms as president of the Central Conference of American Rabbis, and eventually being offered the presidency of HUC but rejecting it due to his other commitments relating to labour and environmental issues. ${ }^{3}$ In terms of his religious worldview, Krauskopf was very much a radical; even among Reform Jews at that time, he was unusually explicit about his hope for a reconciliation of Jew and Christian in a shared religion of the future, for example. ${ }^{4} \mathrm{He}$ was vice-president and chairman of the committee for the radical Pittsburgh Platform in 1885 and, as rabbi of Temple Keneseth Israel in Philadelphia (from 1887), he almost immediately initiated its reforms, including Sunday services. ${ }^{5}$ Furthermore, of all the Reform thinkers in his day, Krauskopf was the one most enamoured by science. For him, science perfectly complemented religion and there was absolutely no need to choose between their claims. The only threat lay in failing to make the nature of their complementarity clear to an increasingly doubtful Jewish public.

Krauskopf's series of sermons Evolution and Judaism was given in the winter of 1886 and collated and published in 1887. It was written primarily for a Jewish congregational audience, but with a Christian readership in mind, too, and included many references to Christian authorities. ${ }^{6}$ It was not the earliest Jewish treatment of the subject or even the earliest Reform Jewish treatment, but it was the most lengthy and comprehensive, with specific sermons discussing the theory in a variety of contexts including the Bible, the history of religion, modern cosmology, palaeontology, the implications for understanding

\footnotetext{
2 Of the 23 candidates who entered HUC in 1875 only four graduated in 1883 ; at the time, the issue of Reform's attitude to dietary regulations was undecided and the notorious graduation banquet (the "treyfa banquet") would offend many and was a factor in the emergence of Conservative Judaism.

${ }^{3}$ For a useful biography, see William W. Blood, Apostle of Reason: A Biography of Joseph Krauskopf (Philadelphia: Dorrance \& Co., 1973). The National Encyclopedia of American Biography vol.3 (1891) has an entry for Krauskopf that describes him as the leading exponent of Reform Judaism in the United States. He served two terms as the president of the Central Conference of American Rabbis (CCAR), 1903-05. During his career he held many advisory and committee positions for the government including work for the National Relief Commission (1898), the US Department of Agriculture (1900, 1917), the American Association for the Advancement of Science (1904), the Food Conservation Commission (1917), and the American Red Cross (1917). His life-long work was the development of a National Farm School, established in 1897, which he himself helped finance with various fund-raising initiatives including the proceeds from his Sunday Lectures series.

${ }^{4}$ In this work Krauskopf suggested that "With a rational, purified Judaism, Christianity, as the religion of Jesus, the Jew, will mean the religion of Judaism, pure and simple." Joseph Krauskopf, Evolution and Judaism (Kansas City: Berkowitz, 1887), 309.

${ }^{5}$ The platform, convened under Kaufmann Kohler at Krauskopf's suggestion, stated, among other things, that "We hold that the modern discoveries of scientific researches in the domain of nature and history are not antagonistic to the doctrines of Judaism, the Bible reflecting the primitive ideas of its own age, and at times clothing its conception of divine Providence and Justice dealing with men in miraculous narratives." For the full text of the Platform, and some useful contextual essays, see Walter Jacob, ed., The Changing World of Reform Judaism: The Pittsburgh Platform in Retrospect (Pittsburgh: Rodef Shalom Congregation, 1985).

${ }^{6}$ For example, in a section criticizing anachronistic worship practices and beliefs, Krauskopf listed Jewish practices such as separate seating for men and women, the use of head-coverings and phylacteries, and prayer in Hebrew, alongside beliefs in immaculate conception, faith cures, Jesus' miracles, his vicarious atonement, resurrection and ascension, the doctrine of the Trinity, and baptism and other sacraments as a means to avoid eternal damnation. Krauskopf, Evolution and Judaism, 282-83.
} 
man's intellect, society, religion and morality, and in the context of worship. In terms of a programmatic agenda, his study shared with Isaac Mayer Wise's work on the subject written a decade previously an explicit concern to counter materialistic philosophies. ${ }^{7}$ Krauskopf explained that "the great mass of believers insisted upon bringing certain primitive speculations of a purely scientific nature within the horizons of religion" and that he sought to "remove some of that skepticism which is engendered by poorly understood science" to ensure a modern "rational faith." $8 \mathrm{He}$ readily admitted that religious knowledge could not ignore "the icy breath of skepticism which touches it" and which undermined tradition. He fully accepted that:

Flaws [in its claims] are detected. Its authority is questioned. Its claims and doctrines are subjected to scrutiny. It no longer satisfies the requirements of truth. It is weighed and found wanting. ${ }^{9}$

But Krauskopf's lecture series was explicitly intended to refute the claim of the materialists that Darwin's teachings had a central role in this process, as if such teachings should by necessity "drive God out of nature, and lead to infidelity." 10

\section{A Panentheistic Account of Evolution}

Krauskopf had no time for those who espoused a purely materialistic view of evolution. As far as he was concerned, it was ultimately based upon atomic theory, which represented a set of assumptions that were every bit as mysterious as those behind "theistic evolution" and begged as many questions. For example, "materialistic evolution" was currently unable to explain why something existed rather than nothing, or to account for the profound transitions from dead to living matter, or from vegetable to animal life, or from animal nature to the self-conscious, reasoning, moral nature of man. He mocked the materialist who treated Matter and Force as pre-existent phenomena and as fundamental to reality, and thereby refused to consider what came before and caused them, because of the theological implications. ${ }^{11}$ The other major problem that Krauskopf had with "materialistic evolution" was the significance of the role played by chance. It was selfevidently unreasonable to him to assume that "accident, a mere fortuitous concourse of atoms, should have caused the infinite variety of things, which manifest such wonderful design and adaptability and forethought," 12 and he claimed that many scientists and philosophers, including Haeckel, Darwin, Huxley, and Spencer, recognized this, so that he could claim that the "Materialistic evolutionists [increasingly] become more and more theistic." 13

\footnotetext{
7 Ibid., 38, 60-66. See footnote 1.

${ }^{8}$ Ibid., preface.

${ }^{9}$ Ibid., 6.

${ }^{10}$ Ibid., 13.

${ }^{11}$ Ibid., 66-67.

12 Ibid., 68.

${ }^{13}$ Ibid., 69.
} 
This leads us to perhaps the most interesting aspect of Krauskopf's thought, namely, his alternative conception of nature and of its relation to God. It is true that, when confronting materialistic versions of evolutionary theory, he sometimes used the familiar, biblical language of an intelligent, personal, divine Creator and Law-Giver, ${ }^{14}$ to whom the natural law of development could be attributed. ${ }^{15}$ But such statements need to be set against the wider context of what is more properly described as a panentheistic conception of the deity. ${ }^{16}$ And for Krauskopf, God's immanent presence in nature was made manifest in three specific ways, which we will consider in turn: through the work of natural law, in life itself, and in the evolved intellect.

Particularly in discussions of science where his chief concern was to deny any essential difference between the conclusions of science and of religion, Krauskopf occasionally went so far as to identify natural law with God. This followed from the purpose, order and harmony that he saw underlying design in nature.

$[\mathrm{N}]$ ature is under the power of government under the control of supreme order and uninterrupted harmony, under the reign of ever-present, ever active, never-changing law which shapes all matter, organic and inorganic, according to design, and directs all force, physical and vital, according to purpose, and compels both to be eternally the same in their manifestations. This universally acknowledged supreme governing power ... is named by evolutionists "Natural Law;" by theologians it is called "God." ... With this conception of the nature of God every difference between science and religion disappears. With this perfect agreement with the scientific accounts of the Final Cause, I am prepared to accept ... every plausible theory that science may have to offer. ${ }^{17}$

Insofar as nature was to be understood as the product or expression of natural law, and insofar as another name for natural law was God, then Krauskopf might have been regarded as pantheistic, that is, it identified God and nature. In support of such an interpretation were such incautious comments as when, reflecting upon the monism of Haeckel, he suggested that "By it we arrive at the sublime idea of the Unity of God and Nature."18 But more often for Krauskopf, nature or natural law was only part of the divine

\footnotetext{
14 Ibid., 66.

${ }^{15}$ He explained that "Theistic evolution attempts to prove that the past has given rise to the present by the simple process of development according to God-Created Natural Law, the higher and more complex arising from the preceding simpler and lower." Ibid., 84. And, contrasting the views of the believer in biblical literalism with those of the theistic evolutionist, he asserted a kind of harmonization of God and natural law: "The one makes God act as if He were human, makes Him converse with the serpent and receive answer from her, makes Him walk in the garden in the cool of the day; the other conceives God as invisible and incorporeal, the Supreme Force and Intelligence, establishing eternal and immutable law and acting with it, and never against it." Ibid., 130.

${ }_{16}$ Panentheism can be defined as the idea that all is in God, but that God is greater than all, that is, that God's immanent presence in nature does not adequately delimit the reality of God. It can be contrasted with pantheism which is the idea that all is God and God is all, that is, that God is to be identified with the totality of nature. Blau also identifies a pantheistic element to Krauskopf's thought. Joseph Blau, "An American-Jewish View of the Evolution Controversy," Hebrew Union College Annual XX (1947): 630.

${ }_{17}$ Krauskopf, Evolution and Judaism, 102-4. And again: "[W]e see greater evidence of the marvels of God's handiwork [via evolution] then ever we could glean from a belief in special creation ... [W] see God constantly creating ... we see all nature reveal the ever present and constantly active final cause ... This sum of Supreme Will, Supreme Power, Supreme Intelligence, evolutionists name 'The Reign of Natural Law,' the theologians call it 'God.', Ibid., 116-17.

18 Ibid., 239. The monism of the German biologist and philosopher Ernest Haeckel (1834-1919) was of considerable interest to Krauskopf. As it appeared in Haeckel's work, monism is a mechanistic view of organic life and physical nature as a unified whole, which includes social phenomena and mental processes; as such, life only differs from inorganic nature in the degree to which it is organized. Spinoza also featured prominently in Haeckel's
} 
reality, not its entirety, so that he could say: "All existence is part of His existence, all life is part of His life, all intelligence is part of His intelligence, all evolution, all progress is part of His plan." 19

In one of the most autobiographical sections of the book, Krauskopf confessed that he had taken much comfort from such a conception, since, in moments of doubt, he could reconcile his religious belief in God with the claims of science, and at the same time offer an alternative to the distant, transcendent God of the philosophers. While God might be conceived as the first cause, he was also the natural law that drove evolution to raise inorganic matter to organic. Furthermore, and this was the second sense in which God's presence in the natural world was to be located, the universe was not a dead cosmos but a living one, and could itself be viewed as a kind of living organism, and that the life force itself was to be associated with the divine, and as something distinct from the universe itself and the natural laws that formed it.

Here I could see Him as the Eternal and Immutable Law, directing all matter, organic and inorganic, all force, physical and vital, and gradually developing all life from the simplest to the more and more complex, from the crudest to the more and more perfect, from the not living to life ... Here was no metaphysical God, thinkable only in negative attributes. Here were positive effects, all flowing from a positive First Cause. Here I could see Him constantly active and eternally creating, the Cause of all Life, the Life of all Cause, and I named Him "the Universal Life." ... I beheld the whole universe as a living and growing organism, thrilled in its every fiber with "the Universal Life," and my reason was humbled by the sublimity of this conception, and my heart was moved to adore the Creator of it all, as the "Cause of All" and as the "Cause in All." ${ }^{20}$

Here as elsewhere, ${ }^{21}$ Krauskopf asserted that the divine was to be found not only in natural laws but in the phenomenon of life itself, which reflects the influence of the Christian evolutionist Henry Ward Beecher's similar claims about

a God universally diffused, to such an extent that whenever there is a force, there is God behind that force ... Though Agnostic and Atheistic reasoners should rename God, and call Him "Force" or "Energy," I care not ... and if there be one thing that is to be triumphantly demonstrated by Evolution, it is that the whole life of the world is permeated by the life of God himself." 22

It is at this point, however, that Krauskopf proceeded to develop what was perhaps the most distinctive aspect of his theistic evolutionist theory, and one that was calculated to confound the pessimism of the materialists, namely, that evolution continued beyond the

\footnotetext{
writing in relation to the "pantheism" and "natural religion," and God was defined as "necessity" and as "the total of all force and therefore of all matter." See, for example, Ernst Haeckel, Generelle Morphologie Der Organismen [General Morphology of Organisms] (Berlin: Georg Reimer, 1866).

${ }^{19}$ Krauskopf, Evolution and Judaism, 279-80.

${ }^{20}$ Ibid., 244-45.

${ }^{21}$ For example, in relation to germinal cell building he enthused: "I am filled with awe at the wonder of wonders, and in this, too, I behold the manifestation of God, I behold the presence of God." Ibid., 72.

${ }^{22}$ Henry Ward Beecher, Evolution and Religion, 2 vols. (New York: Fords, Howard, \& Hulbert, 1885), 78.
} 
grave. Drawing upon Jewish mysticism and the divine sparks of Lurianic kabbalism, ${ }^{23}$ he argued that:

The same life-principle that throbs in us to-day throbbed in us when we were yet a protoplasm and will throb in us when we shall become even as our God. If matter is indestructible, if force is persistent, who dare claim that life alone is perishable? Life is a spark of "the universal Life," and "the universal life" is God ... At the dawn of time into each of us a spark of "the universal life" was breathed with the divine necessity to carry it forward, to develop and unfold it until the ultimate goal is reached. That spark has been clothed in many a garb, and has assumed many a shape. It has advanced through every stage of the lower species, and will advance through every higher state to come, until the God-like will be reached. When developing time comes, the unfolding life-principle forces the petals outward, they break and wither, but the seed lives. When developing time comes the caterpillar-crysalis [sic] shuffles off its old and uncouth coil and becomes the golden winged butterfly. So, too, when developing time comes in the slow unfolding of or spark of life, the mortal coil is returned to its primal earthly elements, is wept for and mourned over, while the spark of live lives and passes on to a higher and better state. ${ }^{24}$

There is some disagreement among commentators as to whether Krauskopf here dismisses personal immortality in favour of some kind of life-principle. But the example given is of an individual organism's metamorphosis, and Krauskopf returned to the idea a few years later, suggesting that of the many arguments supporting the doctrine of immortality, "the evolution-argument is one of much force." He argued that:

Man may not be the highest development attained by creation ... The coffin of the material may be the cradle of the spiritual, and the much-dreaded death may only be the means of conveying imperfect man to a higher state of existence, just as the larva is the means of changing the loathsome caterpillar into the beauteous butterfly. ${ }^{25}$

The third way in which Krauskopf thought about divine immanence in relation to nature was in regard to the evolution of the intellect. In its most developed form, in mankind, the awakening of the intellect could be regarded as a kind of divine revelation or as a manifestation of the essence of God. But for Krauskopf, evolutionary theory suggested that, in a very real biological sense, this was necessarily a phenomenon shared with all of life, to a greater or lesser extent. His theory was that:

[A]ll intellect begins at the base of the column of animal life, and ever widens in its gradual rise towards the top, reaching its widest sweep in man; that as intellect manifests itself as Revelation of God at the top, it is the same revelation beneath[;] that remembering the vast difference between man and the lower animal in limitations of vital force and physical functions and anatomical structure, the animal low in the scale possesses, qualitatively as much of the essence of God, as does man; that intellect advances in its rise along the column, in a fixed series of

\footnotetext{
${ }^{23}$ In general, the modernist Krauskopf tended to associate Jewish mysticism with medieval Jewish theology, and was certainly not as interested in the subject as was, for example, Isaac Mayer Wise. Krauskopf, Evolution and Judaism, 235.

${ }^{24}$ Ibid., 264-65.

${ }^{25}$ Joseph Krauskopf, “After Death - What?," Miscellaneous Sunday Lectures, pamphlet series, lectured delivered 14 December 1890 (Philadelphia, [1890/91?]), 9. It is by no means clear that Krauskopf views this to mean the end of the individual.
} 
geometrical progression, increasing with every increase of structural complexity or with the increasing obstacles in the struggle for existence. ${ }^{26}$

Since the intellect had developed through evolutionary processes, qualitatively if not quantitatively, it was to be found throughout the tree of life.

\section{Biblical-Criticism}

All this had implications for how Krauskopf approached the Bible, since contemporary intra-Jewish debates about biblical-criticism were at the forefront of Krauskopf's mind when it came to discussing evolution, as they had been for other contemporary Reform treatments. ${ }^{27}$ But in contrast to these others who sought to reconcile the biblical accounts of creation with the findings of science, one way or another, Krauskopf made no attempt to retain the dignity of the scriptures. If, he insisted, one truly adopted the perspective of theistic evolution "that our whole universe has been developed from a primal nebula," then:

[L]et us go the whole way, and not twist the Hebrew word "Barah" (to create) into meaning "gradual unfolding." It means what it was intended to mean, "Creatio ex nihilo" ... [Let us] not try to patch up the Bible into teaching universal solar systems, when it plainly means that the earth is the All ... and [let us] not try to account for discrepancies and errors by arguing that God had to use an unscientific method, for the primitive Hebrews were not sufficiently advanced. ${ }^{28}$

Instead, quite deliberately, he pointed to natural science as offering an alternative source of revelation from that of the traditional textual sources. In comparing a zealous believer in the literal reading of the Bible and a theistic evolutionist, he suggested that:

The [biblical literalist] supports all his beliefs by the authority of a collection of ancient books, which he believes to be inspired, not on any scientific basis, but on the basis of simple, unquestioning faith. The [theistic evolutionist] supports his claims by the teachings of a sacred volume, too, very old, as old as time and as voluminous as space, whose countless pages unfold the records of all the ages that have ever been, and show faithful illustrations of all the life that has ever existed, their joys and sorrows, their trials and tribulations, their rise and their fall, their appearance and disappearance, their struggle and their final triumph. The name of this volume is inscribed upon the title page in God's own handwriting. It reads: "Nature."29

It seems that for Krauskopf the question of how one might reconcile the findings of biblical-criticism with tradition was of far less interest than was the idea of a future Judaism

\footnotetext{
${ }^{26}$ Evolution and Judaism, 152-53.

${ }^{27}$ For a fuller discussion of this subject, see Naomi W. Cohen, "The Challenges of Darwinism and Biblical Criticism to American Judaism," Modern Judaism 4, no. 2 (1984).

${ }^{28}$ Krauskopf, Evolution and Judaism, 55-57. Likewise, he rejected claims for "creation from nothing" in the Talmud (BT Rosh Hashanah 11a, Chulin 60a) and in Maimonides' writings (Moreh Nebuchim 2:30). Ibid., 55, 84.

${ }^{29}$ Ibid., 131.
} 
that might simply jettison the idea of textual revelation and turn instead towards the natural world and natural science for inspiration.

\section{Conclusion}

With his book Evolution and Judaism, Krauskopf had sought to persuade his congregants that the challenges of materialism and scepticism towards Jewish tradition as epitomized in evolutionary theory were not fatal to Jewish religion, properly understood. There were certainly striking contradictions in his thought, such as his claims that the natural law was both God-created and God. ${ }^{30}$ His panentheistic account of evolution was also a strange mixture of ideas. And, like so many others in his own day, he was repelled by some aspects of Darwinian natural selection and so tended to offer an account of biological evolutionary theory that was more palatable to theistic evolutionists. But, as a leading Reform Rabbi at a time when Reform Judaism was beginning its ascendency in the U.S., his was a welcome message of hope for many. Reform rabbis before Krauskopf had been much more defensive in seeking to reconcile evolutionary science with Judaism. Krauskopf, in contrast, was unequivocal in privileging the authority of science over tradition. Or to put it more accurately, he attempted to privilege a specific conception of science that was premised upon theistic assumptions, while at the same time to justify the rejection of philosophical materialism. On the one hand, this allowed him to argue that, against the pessimistic claims of materialism, his theistic evolutionary theory promised survival beyond the grave. On the other hand, he appeared to enjoy articulating the radical implications of a sceptical approach to Jewish tradition and scriptures, and was unperturbed by any concern caused by his acceptance of the basic materialist premise that the universe operated free from any personal, interventionist deity, but was rather the expression of natural law, which he called God. If the cost of meeting the challenge of the materialist evolutionists was an unfamiliar conception of God as the de-personalized evolving force behind nature, then that was a price worth paying for rabbi Krauskopf. And this approach would be followed by others, including, most famously, Mordecai Kaplan. ${ }^{31}$

\section{BIBLIOGRAPHY}

Beecher, Henry Ward. Evolution and Religion. 2 vols. New York: Fords, Howard, \& Hulbert, 1885.

Blau, Joseph. “An American-Jewish View of the Evolution Controversy.” Hebrew Union College Annual XX (1947): 617-34.

Blood, William W. Apostle of Reason: A Biography of Joseph Krauskopf. Philadelphia: Dorrance \& Co., 1973.

\footnotetext{
${ }^{30}$ As Blau puts it, for Krauskopf "God is both Law and the Creator of the Law." Blau, "An American-Jewish View of the Evolution Controversy," 627, 629.

${ }^{31}$ For a comparative study of Kaplan on this subject, see Daniel R. Langton, "Jewish Religious Thought, the Holocaust, and Darwinism: A Comparison of Hans Jonas and Mordecai Kaplan," Aleph: Historical Studies in Science and Judaism 13, no. 2 (2013).
} 
Cohen, Naomi W. "The Challenges of Darwinism and Biblical Criticism to American Judaism." Modern Judaism 4, no. 2 (1984): 121-57.

Haeckel, Ernst. Generelle Morphologie Der Organismen [General Morphology of Organisms]. Berlin: Georg Reimer, 1866.

Hirsch, Emil G. Darwin and Darwinism: A Discourse Delivered before the Chicago Sinai Congregation. Chicago: Occident, 1883.

- "The Doctrine of Evolution and Judaism." In Some Modern Problems and Their Bearing on Judaism. Reform Advocate Library, 25-46. Chicago: Bloch \& Newman, 1903.

—_. "Evolution." In Jewish Encyclopedia, edited by Isadore Singer, 281-82. New York: Funk and Wagnalls Company, 1901-1906.

"Evolution in Religion." The Jewish Advance, 6 May 1881, 5.

Jacob, Walter, ed. The Changing World of Reform Judaism: The Pittsburgh Platform in Retrospect. Pittsburgh: Rodef Shalom Congregation, 1985.

Kohler, Kaufmann. "Adam: Or Man in Creation.” The Jewish Messenger, 24 October 1879, 5.

- "Evolution and Morality." Temple Beth-El Lectures, pamphlet series, lecture delivered 4 December 1887, 1-8. New York, [1887/88?].

- Jewish Theology: Systematically and Historically Considered. New York: The Macmillan Company, 1918.

"Science and Religion." The Jewish Times, 20 February 1874, 820-21.

Krauskopf, Joseph. "After Death - What?” Miscellaneous Sunday Lectures, pamphlet series, lecture delivered 14 December 1890, 1-12. Philadelphia, [1890/91?].

. Evolution and Judaism. Kansas City: Berkowitz, 1887.

Langton, Daniel R. "Isaac Mayer Wise, Cosmic Evolution, and the Problem of Evil." In Chance or Providence? Religious Perspectives on Divine Action, edited by Louise Hickman, 79-94. Cambridge: Cambridge Scholars Publishing, 2014.

_ . "Jewish Religious Thought, the Holocaust, and Darwinism: A Comparison of Hans Jonas and Mordecai Kaplan." Aleph: Historical Studies in Science and Judaism 13, no. 2 (2013): 311-48.

Wise, Isaac Mayer. The Cosmic God: A Fundamental Philosophy in Popular Lectures. Cincinnati: Office American Israelite and Deborah, 1876. 